\title{
A computerized system to conduct the Tweed-Merrifield analysis in orthodontics
}

\section{Sistema computadorizado para conduzir a análise de Tweed- Merrifield na ortodontia}

\author{
Maximino Brandão Barreto* \\ Eduardo Machado Fonseca** \\ Antônio José Ledo Alves da Cunha***
}

\begin{abstract}
Precision in orthodontic diagnosis can increase the chance of therapeutic success. The objective of this study was to describe the development of a computerized system (prototype), created from a printed table of the Cranial Facial Analysis and Total Dentition Space Analysis with Difficulty Index - Tweed-Merrifield Analysis - in order to aid orthodontic diagnosis. The analysis was transposed from the manual format to the digital format. A user-logical and clear interface was sought for the development of the prototype, consisting of tables and graphs, including automatic, fast and accurate calculations. The result was the immediate visualization of the resolution of the analysis after filling out the fields on the computer. This technological innovation can be a helpful instrument for the orthodontist that favors a more accurate dental-cranial-facial analysis, increases patient safety, orients conduct and may contribute to teaching and research.
\end{abstract}

DESCRIPTORS: Orthodontics; Cephalometry; Medical informatics.

RESUMO: A precisão no diagnóstico ortodôntico pode aumentar a chance de êxito terapêutico. Este trabalho teve como objetivo descrever o desenvolvimento de um sistema computadorizado (protótipo), criado a partir de uma tabela impressa da Análise Craniofacial e Análise do Espaço Total com o Índice de Dificuldade - Análise de TweedMerrifield, que visa auxiliar o diagnóstico ortodôntico. Foi aplicada a transposição da análise do formato manual para o digital. Buscou-se uma interface lógica e simples para o desenvolvimento do protótipo, composta por tabelas e gráficos, incluindo a realização de cálculos automáticos rápidos e precisos. O resultado foi a visualização imediata da resolução da análise, após o preenchimento dos campos no computador. Essa inovação tecnológica pode ser um instrumento de auxílio ao ortodontista, favorecendo a obtenção de um diagnóstico dentocraniofacial mais acurado, aumentando a segurança do paciente, orientando a conduta e pode contribuir para o ensino e a pesquisa.

DESCRITORES: Ortodontia; Cefalometria; Informática médica.

\section{INTRODUCTION}

Allied to the clinical examination, accurate diagnosis and detailed planning should precede treatment so that the orthodontist has a greater chance of success.

Technological development has impacted on orthodontic practice. Computerized systems are widely used, making digital formats usual in obtaining photos, radiographs, cephalometric landmarks, linear and angular measurements and treatment planning to make up patients' records ${ }^{5,11}$.

To meet this demand, the Tweed-Merrifield Analysis ${ }^{8}$ on the computer is being presented as an innovation. It is found in manual format in the revision of the available literature, from where the study started for digital transposition, producing a prototype to aid orthodontic diagnosis.

\section{MATERIALS AND METHODS}

To start the process of creation and development, the author, two programmers experienced in Visual Basic (Microsoft) language and a systems analyst formed a team. Periodic meetings were held when progress was reported and problems were discussed. New versions were produced to solve them. The last version (Beta) was considered satisfactory - the prototype.

\footnotetext{
* Graduate Student; *** $\mathrm{PhD}$, Director - Institute of Pediatrics, Federal University of Rio de Janeiro.

** Specialist in Orthodontics, Estácio de Sá University.
} 
Barreto MB, Fonseca EM, Cunha AJLA. A computerized system to conduct the Tweed-Merrifield analysis in orthodontics. Braz Oral Res 2006;20(2):167-71.

\section{RESULTS}

To demonstrate the results, the case of female patient A.T.S., 27 years old, was used. It is presented in the form of five figures: two tables containing phase " $A$ " (Figures 1 and 2), two tables containing phase "B"
(Figures 3 and 4) and one Cartesian graph (Figure 5 shows phases "A" and "B"). The tables compose the Tweed-Merrifield Analysis, in digital format, divided into two parts, with a link via Internet to the Tweed International Foundation for Orthodontic Research (www.tweedortho.com):
FIGURE 1 - In the table and horizontal graph of the Total Cranial-Facial Difficulty, a predominance of horizontal skeletal difficulty (45 or $52 \%$ ) over the vertical (37 or $43 \%$ ) and facial difficulties (4 or $5 \%$ ) is observed in phase " $\mathrm{A}$ " or pre-treatment.

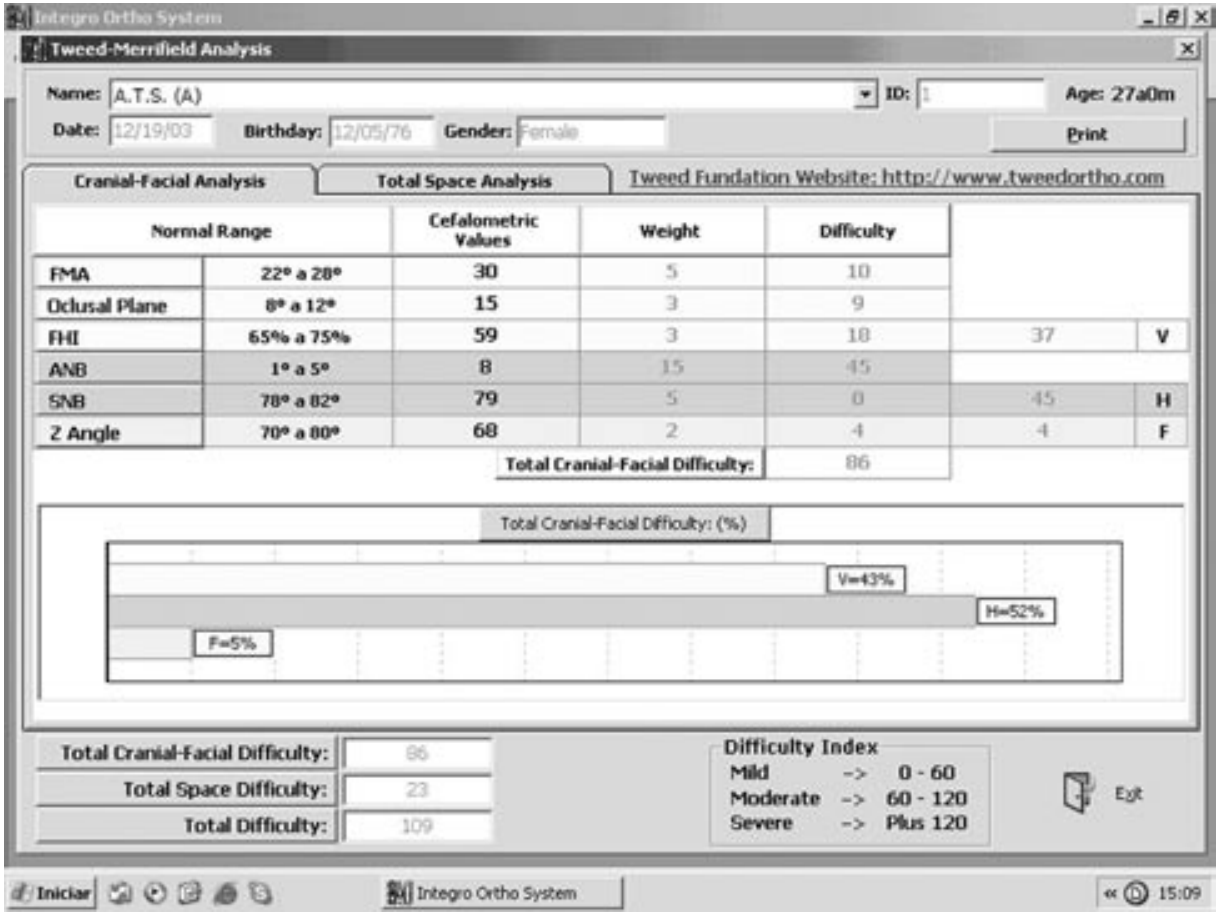

FIGURE 2 - Diagnostic data of the Total Space Analysis - in the table (A, $\mathrm{M}, \mathrm{P})$ and horizontal graph - are presented, showing a predominance of difficulty in the posterior arch (10 or $43 \%$ ) over that of the anterior

(6.9 rounded to 7 or $29 \%$ ) and middle arches (6.5 rounded to 6 or $28 \%$ ), and a Moderate Difficulty Index (109) in phase "A" of the same case.

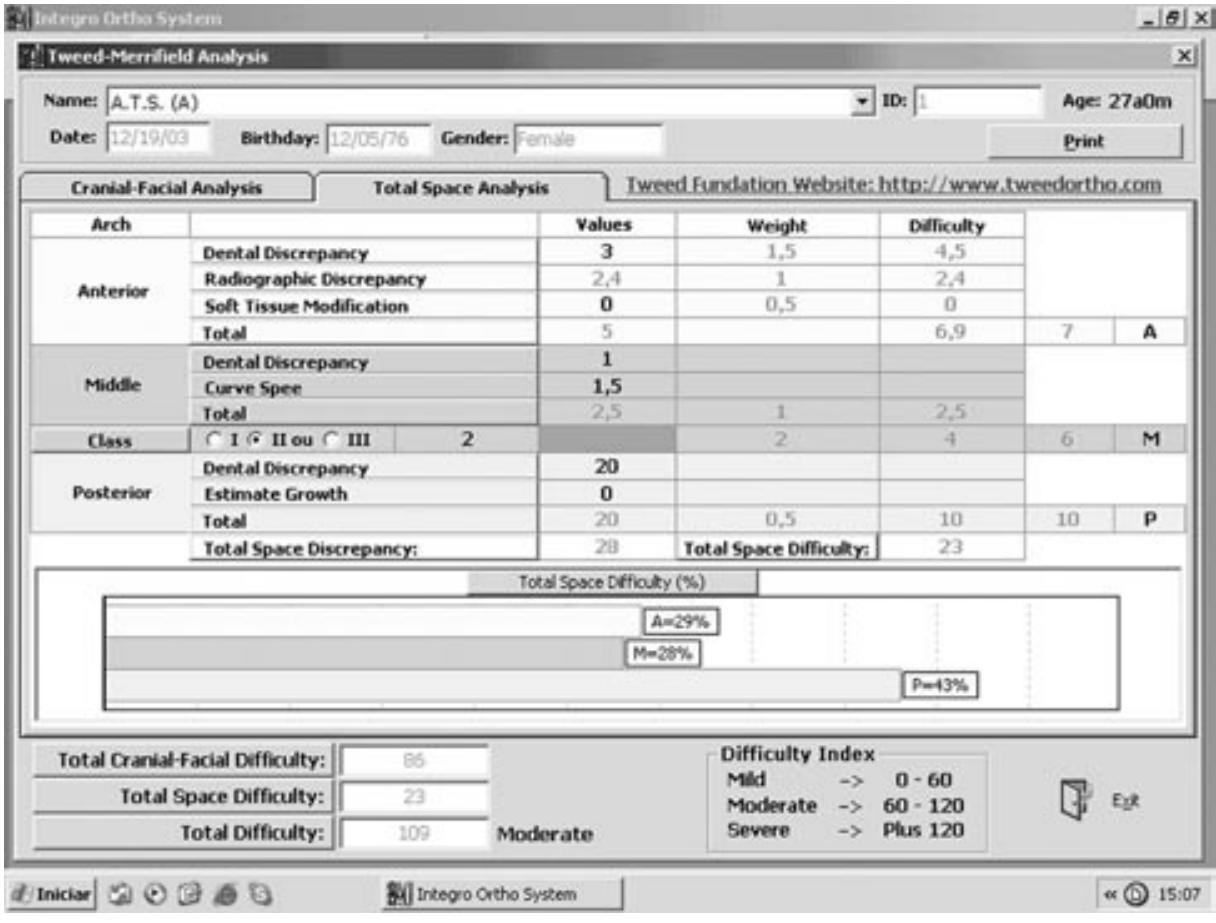


Barreto MB, Fonseca EM, Cunha AJLA. A computerized system to conduct the Tweed-Merrifield analysis in orthodontics. Braz Oral Res 2006;20(2):167-71.

Cranial-Facial Analysis and Total Space Analysis, containing graphs consisting of horizontal bars presented by Horn ${ }^{7}$ (1992), that express, in percentage, the site(s) of greater and lesser concentration of the Cranial-Facial and Dental Difficulties, in a dynamic format. The lower part of four figures (1,2,3 and 4) shows the total of Cranial-Facial and Dental Difficulties, and their sum constitutes the Difficulty Index: $0-60$, mild; 60 - 120, moderate; and 120-plus, severe. Figure 5 shows the new, different reading, with new visualization of the Difficulty Index adapted to the
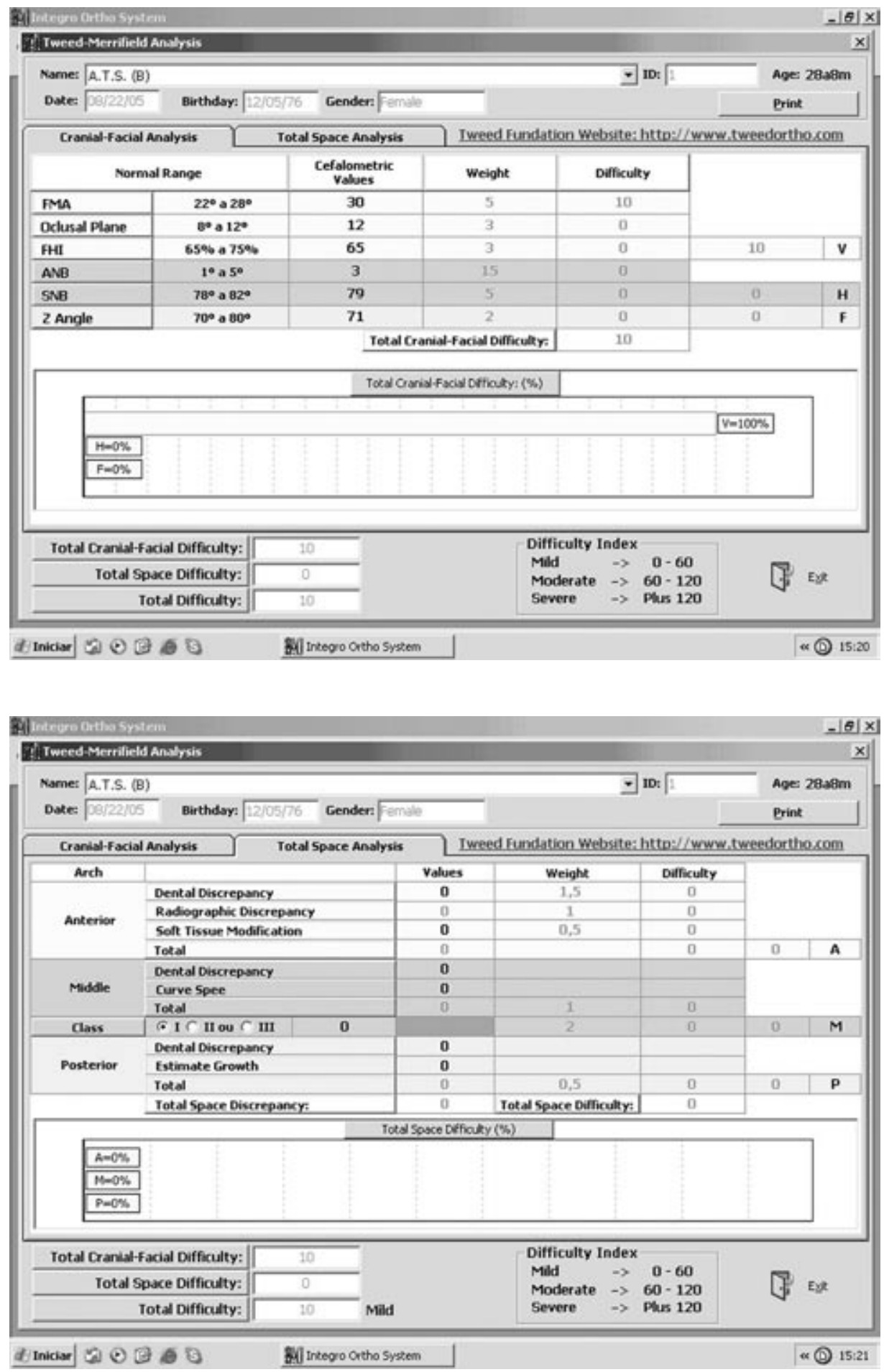

FIGURE 3 - A residual vertical difficulty (10 or $100 \%)$, in the table $(\mathrm{V}, \mathrm{H}, \mathrm{F})$ and horizontal graph of the Total Cranial-Facial Difficulty, is observed in phase "B" or post-treatment.
FIGURE 4 - The absence of difficulty $(0$ or $0 \%)$ in the table (A, $\mathrm{M}, \mathrm{P}$ ) and horizontal graph of the Total Space Difficulty is observed in phase "B" of the same case. 
Barreto MB, Fonseca EM, Cunha AJLA. A computerized system to conduct the Tweed-Merrifield analysis in orthodontics. Braz Oral Res 2006;20(2):167-71.

FIGURE 5 - The Barreto and Fonseca Graph shows the Difficulty Index. The Total Cranial-Facial Difficulty is on the $\mathrm{Y}$ axis and the Total

Space Difficulty is on the $\mathrm{X}$ axis. The pre- and posttreatment phases are " $\mathrm{A}$ " $[86$, $23=109$, Moderate] and "B" $[10,0=10$, Mild $]$

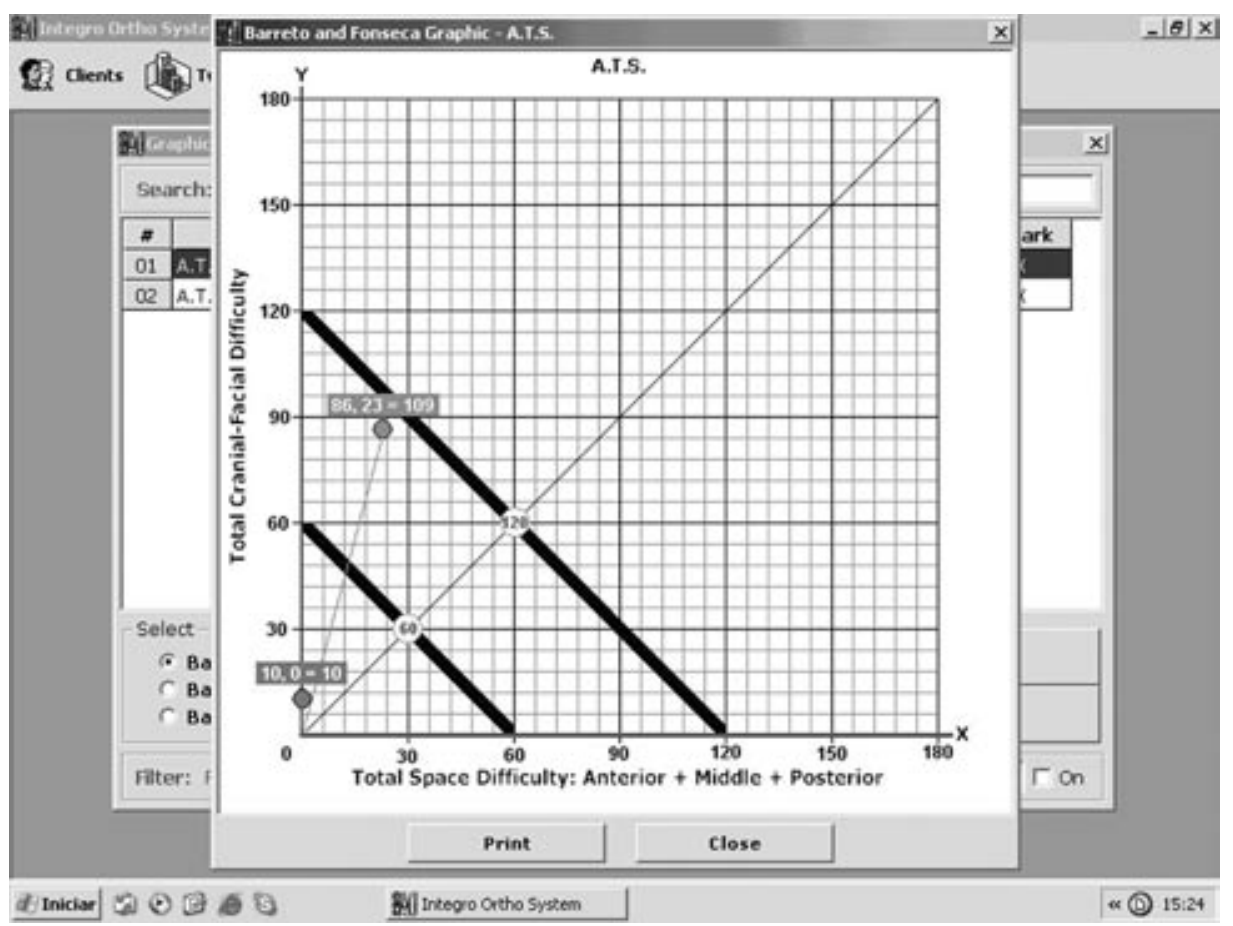

Cartesian graph and called by the author of this article the Barreto and Fonseca Graph. The numerical representation: $\mathrm{Y}, \mathrm{X}=\mathrm{Y}+\mathrm{X}$ was idealized by Harris*. The "Y" is the Total Cranial-Facial Difficulty and the " $X$ " is the Total Space Difficulty. Their sum $(\mathrm{Y}+\mathrm{X})$ is the Difficulty Index.

All the factors in the analysis are also help buttons that, when pressed, take the user to explanatory boxes about the items presented by means of a 3D movie.

\section{DISCUSSION}

Patients' records are very important for the consistency of the decisions to be taken in orthodontic treatment ${ }^{6,9}$. According to Forsyth, Shaw ${ }^{2}$ (1996) orthodontic records based on computerized systems benefit image storage, data transmission and processing. Baskin, Cisneros ${ }^{1}$ (1997) and Gotfredsen et $a l .^{4}$ (1999) reported that various digital systems using radiographic images facilitated cephalometric analysis, executing it directly on the computer screen. Naslund et al. ${ }^{10}$ (1998) and Geelen et al. ${ }^{3}$ (1998) compared manual and digital tracing and found evidence that digital cephalometric tracing reduced errors substantially. The prototype created aims to reduce these errors. Its resources will enable differentiated planning with archive and database generation, facilitating storage and long-distance exchange of information.

There will be greater speed when importing values from the patient's records generated in digital media, enabling automatic data entry. When generated in manual format, the entries should be made in the editing fields, using the keyboard.

This new tool permits the assessment of the degree of severity of the malocclusion, the location of the site or sites of greater predominance and the possibility of persuading the patient and/ or his guardians to collaborate for the success of the treatment, showing his skeletal, dental and/or facial problems on the computer screen or printed.

\section{CONCLUSION}

The creation of a product that combines the use of information technology with a consistent

\footnotetext{
* Harris GS. Graphic Display of Total Space Analysis Data, presented before the Fifteenth Biennial Meeting of the Charles H. Tweed International Foundation for Orthodontic Research: Los Angeles, California; 1984.
} 
Barreto MB, Fonseca EM, Cunha AJLA. A computerized system to conduct the Tweed-Merrifield analysis in orthodontics. Braz Oral Res 2006;20(2):167-71.

analysis to aid orthodontic diagnosis will be a relevant contribution to the improvement of orthodontic care. It increases the safety of the patient and proposes an optimization of treatment planning. It also provides support in the field of teaching and research, enhancing the capacity to control a great

\section{REFERENCES}

1. Baskin HN, Cisneros GJ. A comparison of two computer cephalometric programs. J Clin Orthod 1997;31:231-3.

2. Forsyth DB, Shaw WC, Richmond S. Digital imaging of cephalometric radiography. Part I: advantages and limitations of digital imaging. Angle Orthod 1996;66:37-42.

3. Geelen W, Wenzel A, Gotfredsen E, Kruger M, Hansson LG. Reproducibility of cephalometric landmarks on conventional film, hardcopy, and monitor-displayed images obtained by the storage phosphor technique. Eur J Orthod 1998;20:331-40.

4. Gotfredsen E, Kragskov J, Wenzel A. Development of a system for craniofacial analysis from monitor-displayed digital images. Dentomaxillofac Radiol 1999;28:123-6.

5. Gregston MD, Kula T, Hardman P, Glaros A, Kula K. A comparison of conventional and digital radiographic methods and cephalometric Analysis Software: I. Hard Tissue. Am J Orthod 2004;10:204-11.

6. Han U. Consistency of orthodontic treatment decisions relative to diagnostic records. Am J Orthod Dentofacial Orthop 1991;100:212-9. number of variables in clinical studies using profile radiographic cephalograms.

\section{ACKNOWLEDGEMENTS}

\author{
We would like to thank CAPES and UFRJ.
}

7. Horn AJ. Facial height index. Am J Orthod 1992;102:1806.

8. Merrifield LL. Differential Diagnosis with Total Space Analysis. Journal of Charles $\mathrm{H}$. Tweed International Foundation 1978;10-5.

9. Nakajima A, Sameshima GT, Arai Y, Homme Y, Shimizu N, Dougherty H Sr. Two- and Three-dimensional Orthodontic Imaging Using Limited Cone Beam-Computed Tomography. Angle Orthod 2005;75:895-903.

10. Naslund EB, Kruger M, Petersson A, Hansen K. Analysis of low-dose digital lateral cephalometric radiographs. Dentomaxillofac Radiol 1998;27:136-9.

11. Rheude B, Sadowsky PL, Ferriera A, Jacobson A. An evaluation of the use of digital study models in orthodontic diagnosis and treatment planning. Angle Orthod 2005; 75:292-6.
Received for publication on Nov 16, 2005

Sent for alterations on Jan 20, 2006 Accepted for publication on Feb 21, 2006 